\title{
Ubiquitin Carboxyl-Terminal Hydrolase Isozyme L1
}

National Cancer Institute

\section{Source}

National Cancer Institute. Ubiquitin Carboxyl-Terminal Hydrolase Isozyme L1. NCI

Thesaurus. Code C105388.

Ubiquitin carboxyl-terminal hydrolase isozyme L1 (223 aa, $25 \mathrm{kDa}$ ) is encoded by the human UCHL1 gene. This protein plays a role in ubiquitin metabolism. 